\title{
Massive hemorrhage and transfusion in the operating room
}

\author{
Brian Muirhead, MD • Andrew D. H. Weiss, MD
}

Received: 30 January 2017/Revised: 11 May 2017 / Accepted: 20 June 2017/Published online: 17 July 2017

(c) Canadian Anesthesiologists' Society 2017

\begin{abstract}
Purpose In this Continuing Professional Development module, we review the pathophysiology and clinical manifestations associated with massive hemorrhage as well as laboratory investigations and appropriate therapeutic measures. In addition to reviewing the available blood/plasma products and adjunct therapy, we also explore the role of the anesthesiologist in a massive transfusion protocol scenario.

Principal findings Massive hemorrhage can be either anticipated or unexpected. The coinciding presence of acidosis, hypothermia, and hypotension contribute greatly to a poor outcome. Red blood cells not only increase oxygen carrying capacity, but they also play a role in providing hemostasis. While timely laboratory results, including point-of-care testing, are important, transfusion remains a clinical decision. Adjunct therapies other than blood components have contributed to improved outcomes. The pathophysiology of massive obstetric hemorrhage is unique when compared with the non-obstetric population. The approach to massive hemorrhage and its treatment vary considerably from institution to institution.

Conclusions Massive hemorrhage is a multidisciplinary challenge that requires immediate response and communication between clinicians, nurses, other healthcare providers, laboratory testing, and blood banks. Basic knowledge and utilization of available products and therapies are inconsistent. A massive transfusion protocol can be used effectively to reduce
\end{abstract}

B. Muirhead, MD $(\bowtie) \cdot$ A. D. H. Weiss, MD

Department of Anesthesia, University of Manitoba, 2nd Floor

Harry Medovy House, 671 William Ave, Winnipeg,

MB R3E 0Z2, Canada

e-mail: muirhead@mymts.net chaos and ensure that correct treatments and proper dosing occur in a timely manner.

\section{Objectives of this Continuing Professional Development (CPD) module:}

After reading this module, the reader should be able to:

1. Describe both the clinical and pathophysiological manifestations of massive hemorrhage.

2. Correctly order the appropriate blood products with the appropriate dosing and delivery.

3. List other available treatment modalities, besides blood products.

4. Organize a real-time massive transfusion checklist.

\section{Definition and overview}

The definition of massive hemorrhage or massive transfusion varies from institution to institution. The conventional definition of ten units of red blood cells (RBCs) transfused or blood loss of more than one circulating volume in a $24-\mathrm{hr}$ period has been amended to include ongoing blood loss - e.g., four units of RBCs with continued bleeding (some specify a minimum rate per hour). Regardless, evidence of a massive hemorrhage may be apparent clinically well before transfusion has begun.

Massive transfusion remains one of the greatest challenges for the anesthesiologist. It is most commonly seen in acute trauma, complex cardiac surgery, obstetric hemorrhage, and coagulopathic patients, but it may also occur with any intraoperative event. In some cases it can be anticipated, resulting in proper preparation and an 
organized response, or it may be unexpected and lead to an initially chaotic response. Regardless of the context, the goals of treatment in massive hemorrhage are to maintain perfusion pressure and oxygen delivery to organs, stop surgical bleeding, and treat any coagulopathy. While these goals can be achieved through resuscitation with blood products and surgical or radiological intervention, the triad of hypothermia, acidosis, and coagulopathy contribute to increased morbidity and mortality in such scenarios. ${ }^{1-3}$ While laboratory testing, including point-of-care testing, is an important tool in guiding the transfusion, in many instances, the treatment is based on clinical decisionmaking. Massive transfusion implies resuscitation with RBCs and plasma products. Measures that do not involve transfusion of blood products, including cell salvage, antifibrinolytics, electrolyte replacement, and maintenance of normothermia, are also necessary for a favourable outcome. Constant communication between surgeon, anesthesiologist, and blood bank is critical. With all these factors in place, it becomes important to have a planned strategy. For many institutions, a massive transfusion protocol (MTP) can facilitate an organized approach. In addition, an anesthesia checklist can be of value.

\section{Pathophysiology of coagulopathy}

Hemostasis in massive hemorrhage involves four major processes. Primary hemostasis is the formation of a platelet plug involving adhesion, aggregation, as well as vasoconstriction. Secondary hemostasis is achieved through the activation of coagulation factors to generate thrombin. The third event is fibrin clot formation and stabilization, and with the generation of a clot, the fourth process of thrombin inhibition and fibrinolysis is initiated. ${ }^{4}$

When scheduling a patient with a coagulation disorder for any procedure beyond minor peripheral surgery, a detailed plan for responding to blood loss should be created in collaboration with the patient's hematologist. Management of underlying coagulation disorders is outside the scope of this review. However, when such a patient presents for emergency surgery or acute trauma, the authors recommend early consultation with hematology and/or transfusion medicine specialists (depending on the services available at your institution) before blood loss begins, if possible.

With initial blood loss and crystalloid replacement, the ensuing hemodilution can lead to hypercoagulability-as measured by using viscoelastic measures (e.g., thromboelastography (TEG $\left.{ }^{\circledR}\right)$ - in elective surgical patients. The implications for trauma or obstetric patients who come to surgery in a hypercoagulable state are unclear. $^{1}$

Hypothermia causes significant coagulopathy. ${ }^{2,3}$ Though clinical studies have set various definitions for mild hypothermia, $35^{\circ} \mathrm{C}$ being a common upper limit, it is important to emphasize that impaired enzymatic function is continuous, not ordinal, and that the best function occurs at $37^{\circ} \mathrm{C} .{ }^{5}$ Hypothermia causes a reduction in platelet activation due to a combination of direct inhibition and a decline in circulating platelets through sequestration. Activation of the clotting cascade is slowed, fibrinolysis is increased, and synthesis of coagulation factors is reduced. ${ }^{1,3}$

Anemia itself contributes to further coagulopathy as erythrocytes are important providers of adenosine diphosphate, which assists in activating platelets. Erythrocytes also activate platelet cyclooxygenase and provide procoagulant phospholipids, which have a direct role in increasing thrombin generation. ${ }^{1}$ Furthermore, erythrocytes have a rheological effect by clustering in the centre of blood vessels. This results in an increased concentration of platelets at the vessel perimeter where they can be exposed to endothelial trauma, and thus activate and trigger coagulation. ${ }^{1,2}$ This process has a significant effect and has been shown to result in seven times the average concentration of platelets adjacent to the vessel walls. ${ }^{1,3,6}$ There is considerable evidence in animal, human volunteer, and clinical models of a decrease in bleeding time (BT) in thrombocytopenia following a transfusion of RBCs. Nevertheless, the relationship between BT and perioperative blood loss remains controversial, and the clinical significance of a decrease in BT is unclear. ${ }^{1}$ In an actively bleeding patient, there is a paucity of data on the role of hemoglobin concentration or hematocrit on hemostasis, but existing evidence points towards a minimum hematocrit for optimal hemostasis. ${ }^{1,3}$ Hardy et al. suggest that, in the context of active bleeding and massive transfusion, a hematocrit as high as $35 \%$ may be required for sustained hemostasis. ${ }^{1}$ The literature oscillates between using hematocrit and hemoglobin concentration, but in the patient without macrocytic or polycystic anemia, they are tightly correlated with a hematocrit of $35 \%$ corresponding to a hemoglobin concentration of $105-115 \mathrm{~g} \cdot \mathrm{L}^{-1}$.

Depletion of coagulation factors has become an issue of concern in the modern era of transfusion of fractionated blood products, with hypofibrinogenemia occurring first, followed by a critical reduction in prothrombin, factor $\mathrm{V}$, platelets, and factor VII, respectively. Fibrinogen levels of 1.5-2.0 $\mathrm{g} \cdot \mathrm{L}^{-1}$ have become the threshold for fibrinogen replacement in non-pregnant patients. ${ }^{1,8}$ Platelets are critical for their role in binding to fibrinogen to form 
"platelet plugs" that adhere to collagen and von Willebrand factor (VWF) on vessel walls. Clinically important thrombocytopenia rarely occurs during massive transfusion until approximately one blood volume is lost. This is due in part to the concentration of platelets near the vessel walls, as previously described, as well as release of sequestered platelets and early release of new platelets from the bone marrow. ${ }^{1}$

\section{Pregnancy and hemostasis}

Pregnancy is a period of deranged hemostasis, with a significant increase in procoagulant factors V, VIII, IX, X, XII, and VWF, as much as a twofold increase in fibrinogen, and up to a $1,000 \%$ increase in factor VII. ${ }^{9,10}$ Levels of the anticoagulant factor protein $\mathrm{C}$ are unaltered, though resistance to activated protein $\mathrm{C}$ increases, and levels of both free and bound protein $\mathrm{S}$ decrease from the first trimester. ${ }^{9}$ There is a decrease in primary fibrinolytic activity during pregnancy until the early postpartum period, which is well described and occurs despite an increase in tissue plasminogen activator activity during pregnancy. This is balanced by an increase in plasminogen activator inhibitor-1 and plasminogen activator inhibitor-2 (which is detectable only during pregnancy). ${ }^{9,10}$ It should be appreciated that the coagulation system is teetering on a knife edge in pregnancy, with a four to tenfold increase in the risk of thrombosis. ${ }^{9}$ This likely reduces the risk of maternal morbidity and mortality from bleeding, but the hematologic balance during pregnancy can appropriately be described as "chronic compensated disseminated intravascular coagulation". 11 It must be recognized that, if levels of fibrinogen are at normal non-pregnant levels during hemorrhage, they are critically low for an obstetric patient. $^{12,13}$

\section{Blood and plasma product considerations}

Red blood cells have a hematocrit of 0.45 and a storage limit of 42 days. Collection date and expiry date are indicated on the collection bag. If the transfusion is not started within $30 \mathrm{~min}$, after removal, the collection bag should be returned to the temperature-controlled refrigerator. ${ }^{14}$ The role of ensuring adequate oxygen carrying capacity may be met with hemoglobin targets of 70-90 $\mathrm{g} \cdot \mathrm{L}^{-115}$ however, in massive hemorrhage, the role of $\mathrm{RBCs}$ in hemostasis is to promote platelet activation and migration to the endothelium. ${ }^{1}$ For this reason, a higher target hematocrit may be indicated. Whenever possible, RBCs under pressure should be transfused through largebore catheters to prevent a hyperkalemic load (secondary to hemolysis due to the age of the stored RBCs and from small catheters). The potassium $\left(\mathrm{K}^{+}\right)$load of stored blood increases with the duration of storage, with 14-day-old RBCs having a $\mathrm{K}^{+}$of $10-30 \mathrm{mMol} \cdot \mathrm{L}^{-1} \cdot{ }^{16}$ Rapid central administration of cold RBCs can expose the heart to a solution resembling the cold cardioplegia of cardiac surgery, ${ }^{16,17}$ and rapid infusion of RBCs has been linked to many hyperkalemic perioperative pediatric cardiac arrests. $^{18}$ For small patients, central administration and situations of low cardiac output increase the risk of hyperkalemic cardiac arrest. ${ }^{16}$ Recent studies have shown that there is no difference in outcome based on the age of stored RBCs. ${ }^{19,20}$ Because of a limited supply of O negative donor red cells, $\mathrm{O}$ positive red cells can be substituted for adult males when their ABO group is unknown and for adult females with no childbearing potential. ${ }^{21}$

Frozen plasma (FP) can be derived from random donors or from apheresis donors as apheresis fresh frozen plasma (FFPA). Frozen plasma units are $250 \mathrm{~mL}$ and FFPA units are approximately $500 \mathrm{~mL} .^{14,22}$ Plasma should be ordered by weight $\left(10-15 \mathrm{~mL} \cdot \mathrm{kg}^{-1}\right)$ rather than by units (two units of plasma could be 500-1,000 mL). After thawing, frozen plasma can be stored at $1-6^{\circ} \mathrm{C}$ for up to $120 \mathrm{hr}$. The concentration of fibrinogen in plasma is approximately 2.5 $\mathrm{g} \cdot \mathrm{L}^{-1}$ (Table), ${ }^{23}$ contributing to the correction of hypofibrinogenemia in the massive transfusion patient. This may not hold true in the obstetric patient with a massive hemorrhage, as a higher fibrinogen level is required and plasma may actually cause a dilution of normal obstetric fibrinogen levels. ${ }^{12}$

Platelets are buffy coat derived from pools of four units (five units in Quebec). Their shelf life with storage at $20-24^{\circ} \mathrm{C}$ varies from five to seven days (depending on the degree of pathogen testing). Many institutions recommend that platelets should be transfused through a fresh transfusion filter and should not be used in a blood warmer or rapid infuser; however, there is little data to support this recommendation. Also, ABO/RH compatibility is preferable but not necessary. ${ }^{14}$ Each dose of platelets should increase the count by $15-25 \times 10^{9} \cdot \mathrm{L}^{-1}$.

Cryoprecipitate contains factor VII, factor VIII, fibrinogen, and VWF. The fibrinogen level in each unit of cryoprecipitate is highly variable (Table). One unit of cryoprecipitate per $10 \mathrm{~kg}$ of body weight will increase the fibrinogen level by about $0.5 \mathrm{~g} \cdot \mathrm{L}^{-1}$. The target threshold of $1.0 \mathrm{~g} \cdot \mathrm{L}^{-1}$ has been pushed up to $>1.5 \mathrm{~g} \cdot \mathrm{L}^{-1}$ in many institutions ( $>2.5 \mathrm{~g} \cdot \mathrm{L}^{-1}$ in obstetric hemorrhage). Clinical status may preclude waiting for laboratory confirmation of hypofibrinogenemia. ${ }^{1,14}$

Fibrinogen concentrate (FC) has been approved by Health Canada and is increasingly available. Although clinical trials comparing FC with cryoprecipitate are pending, FC does have the advantage of undergoing a more effective pathogen reduction process, and it also has a 
30-month storage time at room temperature. The product is stable in solution for eight hours and does not require a blood filter administration set. The dose per vial of FC is 0.9-1.3 g (Table).

Prothrombin complex concentrates are currently indicated for emergency reversal of warfarin therapy. ${ }^{24}$ Ongoing investigations are required to determine if there are more indications.

Recombinant factor VIIa has been shown to be effective in reversing coagulopathy, but it is associated with an increased incidence of arterial thrombosis and cannot be recommended except for last chance salvage. ${ }^{25}$

\section{Adjunct therapy}

There is a variety of adjunctive therapies that can potentially reduce morbidity, reduce allogeneic blood transfusions, and treat or temporize induced coagulopathies to allow correction of medical factors and improvement of clotting. When significant and unexpected blood loss occurs, an early drop in blood pressure frequently ensues, resulting in end-organ hypoperfusion. Rapid replacement of matching fluid volume may be delayed due to limited intravenous access. Placing the patient in an exaggerated lithotomy position or performing a straight leg raise has been shown to increase coronary and cerebral perfusion pressure and to increase cardiac output, respectively, for five but not ten minutes. The Trendelenburg position has been shown not to increase cardiac output in patients after cardiac surgery or when stable under anesthesia. ${ }^{26}$ In the context of sudden blood loss, if either an exaggerated lithotomy position or a straight leg raise is not possible, we suggest up to $5^{\circ}$ of Trendelenburg, or at least bringing the patient to a level position (i.e., avoid keeping the patient in a head-up position). Fluid boluses and transfusion of blood products are ideally administered through large-bore peripheral intravenous cannulae, and establishing these should be an early goal in the massive transfusion scenario. If this is not feasible, a large-bore central catheter (e.g., a sheath introducer catheter or a dialysis catheter) is an appropriate second-line option.

While the initial goal of resuscitation is to increase preload in order to ensure adequate cardiac output, it is also imperative to maintain adequate perfusion pressure to vital organs. A previously healthy patient may be able to tolerate a rapid heart rate and decreased flow for a short period of time, but this may not be true for patients who have cardiac, cerebral, or renal comorbidities. For this reason, vasopressors may be needed as part of resuscitation to promote oxygen delivery to the heart and brain, with the knowledge that some organs and tissues (including kidneys and extremities) may suffer further hypoxic injury.

Although the use and dosing of tranexamic acid in massive hemorrhage remain controversial, the effectiveness of an antifibrinolytic agent as part of the strategy for correction of acute coagulopathy of trauma has become apparent. $^{27}$

The use of intraoperative cell salvage (ICS) therapy is now widely used, but delays in setting up equipment and ongoing confusion among some clinicians regarding its indications and contraindications can limit its effect. Cell salvage may be used in pediatric surgeries and in cardiac, vascular, orthopedic, obstetric, and oncologic surgeries. ${ }^{28-30}$ The use of cell salvage in cancer surgery remains controversial, but there is good evidence that cancer cells are already present within the blood of these patients well before most cancer surgeries, and that cell salvage with the use of leukocyte depleting filters (LDFs) removes nearly all cancer cells. ${ }^{28,30}$ Although high-quality

Table Blood product ordering reference

\begin{tabular}{|c|c|c|}
\hline Blood product & Component & $\begin{array}{l}\text { Expected increase following } \\
\text { in } 70-\mathrm{kg} \text { patient }\end{array}$ \\
\hline \multicolumn{3}{|c|}{ Fibrinogen content of products available for treatment of acquired hypofibrinogenemia } \\
\hline 1 vial fibrinogen concentrate & $0.9-1.3 \mathrm{~g}$ fibrinogen & $0.21-0.31 \mathrm{~g} \cdot \mathrm{L}^{-1}$ fibrinogen \\
\hline $1,000 \mathrm{~mL}$ frozen plasma (ordered as $10-15 \mathrm{~mL} \cdot \mathrm{kg}^{-1}$ ) & $2.94 \pm 0.63 g$ fibrinogen $(1 S D)$ & $0.57-0.89 \mathrm{~g} \cdot \mathrm{L}^{-1}$ fibrinogen \\
\hline 1 unit cryoprecipitate & 0.432 (0.264) g fibrinogen & $0.06 \mathrm{~g} \cdot \mathrm{L}^{-1}$ fibrinogen \\
\hline \multicolumn{3}{|c|}{ Content of products for the treatment of thrombocytopenia and anemia } \\
\hline 1 adult dose platelets & $311-373 \mathrm{~mL} ; 204-422 \times 10^{9} \mathrm{plt}$ & $15-25 \times 10^{9} \cdot \mathrm{L}^{-1} \mathrm{plt}$ \\
\hline 1 unit RBCs & 393-415 mL; 41-71 g Hgb & $10 \mathrm{~g} \cdot \mathrm{dL}^{-1} \mathrm{Hgb}$ \\
\hline
\end{tabular}

Fresh frozen plasma contains significant amounts of fibrinogen, factors II, V, VII, VIII, X

Cryoprecipitate contains significant amounts of fibrinogen, fibronectin, factors VIII, XIII, and von Willebrand factor

$\mathrm{Hgb}=$ hemoglobin; plt = platelets; RBCs = red blood cells. $($ For more detail, please see references 14, 22 and 23) 
randomized trials are lacking, the preponderance of evidence suggests that the use of ICS with LDFs results in no difference in long-term survival or tumour recurrence. ${ }^{28,30}$ The true contraindications to the use of ICS in oncologic surgery are limited to situations where hepatocellular tumours have ruptured intraoperatively. For the contentious situations of massive bleeding with an open bowel or amniotic fluid in the abdomen, expert opinion recommends initial removal of the obvious feculent material with a separate suction. Nevertheless, the presence of feculent material or amniotic fluid in the setting of significant bleeding is not otherwise a contraindication to ICS with LDF. The contamination is managed by increasing the volume of wash solution and using an LDF. This results in transfusates that approximate those from uncontaminated sources. In situations of an open bowel where there is continuity between fecal material and the patient's circulation, the use of broadspectrum antibiotics is indicated, whether or not ICS has been used. ${ }^{28}$ It should be emphasized that negatively charged leukoreduction filters increase bradykinin levels in the transfusate, and that the rapid infusion of blood collected by ICS with leukoreduction to a patient on angiotensin-converting enzyme inhibitors can cause recalcitrant hypotension. ${ }^{31}$

Damage control surgery is described as an approach for severe trauma that focuses on control of contamination and sites of major hemorrhage, with temporary closure and subsequent return to the operating room for definitive repair following correction of acidosis and coagulopathy. This approach has reduced mortality compared with primary definitive repair in major trauma. The critical features of this approach, which are pertinent to any situation of massive hemorrhage, include consideration for packing sites of microvascular bleeding to allow resuscitation and correction of hematologic and metabolic derangements, consideration of total or partial organ resection in contexts where packing is insufficient to tamponade bleeding, consideration of arterial or venous shunt around critical vessel injury to allow for later definitive repair, and the use of intra-arterial embolization by interventional radiology to control hemorrhagic sites not otherwise accessible. ${ }^{32}$

\section{Laboratory testing}

Electrolytes can easily become deranged during massive transfusion and should be measured and replaced on a regular basis in order to avoid the consequences of their derangement. In particular, calcium plays an important role in the coagulation cascade, and it has an inotropic effect on cardiac function. ${ }^{1}$ Because $\mathrm{RBCs}$ are stored in citrate, transfusion of significant amounts of this chelating agent may lead to acute hypocalcemia and require regular calcium replacement. ${ }^{2}$

Though complete blood count, international normalized ratio, and fibrinogen tests performed in a central laboratory provide the most reliable numbers, the typical delay associated with obtaining the results and the dynamic nature of a massive transfusion means that they provide a marker of a former state. Still, they should be sent on a regular basis in order to identify deficits that may not otherwise be apparent or corrected in the interim between test collection and reporting. ${ }^{2}$

Point-of-care testing, which, depending on the institution, can include arterial blood gas analysis, hemoglobin/hematocrit, basic electrolytes, glucose, and/or lactate measurement allows for the timely assessment of various parameters and facilitates management.

Over the last decade, point-of-care or near-patient tests for thrombin generation and total clotting capacity have become available, including TEG and rotational thromboelastometry (ROTEM $\AA)^{33-36}$ Their common elements include placing sample blood in a cuvette with a midline pin. In ROTEM, the pin spins and an optical detector system is used. In TEG, the cuvette spins, the pin is stationary, and torsion is measured in the pin. ${ }^{33,35}$ Both evaluate the speed and strength of clot formation as well as clot stability, with defects in specific metrics being targets for specific interventions. To date, there is no conclusive evidence of a change in either mortality or the incidence of massive transfusion with the use of ROTEM or TEG-guided transfusion. This is due largely to the preponderance of small studies with a high risk of bias, ${ }^{34}$ but the trend points toward a reduction in blood product transfusion, and there is evidence for their effectiveness in cardiac surgery. ${ }^{34}$ The results of the two tests (ROTEM and TEG) are not interchangeable, but their clinical implications are similar. ${ }^{37}$ Reference ranges may vary slightly and must be available for the device used in each institution.

\section{Massive obstetric hemorrhage}

Definitions of massive obstetric hemorrhage include blood loss of $>2,500 \mathrm{~mL}$, transfusion of $\geq$ four units of RBCs, or a fall in hemoglobin concentration of $>40 \mathrm{~g} \cdot \mathrm{L}^{-1} \cdot{ }^{12}$ Common etiologies include uterine atony, surgical trauma, placental abnormalities and abruption, and uterine rupture.

The components of hemostasis in the obstetric patient differ significantly from the non-pregnant patient. Increases in the levels of coagulation factors, including fibrinogen, VWF, and factor VIII, put the parturient in a 
prothrombotic state at term. Fibrinogen levels of 4-6 $\mathrm{g} \cdot \mathrm{L}^{-1}$ are twice as high as in the non-pregnant population. ${ }^{38}$ The concurrent fall in protein $\mathrm{S}$ adds to this prothrombotic state. These changes result in shorter prothrombin and activated partial thromboplastin times (PT/aPTT). For these reasons, PT/aPTT may remain normal despite massive hemorrhage, although fluid resuscitation may cause a dilutional coagulopathy. A prolonged PT/aPTT is an ominous sign in obstetric hemorrhage and should be treated accordingly. Also, due in part to activation of fibrinolysis, a fall in fibrinogen to a level of $2-3 \mathrm{~g} \cdot \mathrm{L}^{-1}$ is an early prognostic sign for massive hemorrhage. ${ }^{12,39}$ In addition to standard laboratory testing, point-of-care testing, including thromboelastometry, can be a valuable tool in assessing hemostasis in obstetric hemorrhage. ${ }^{34}$

As with other massive transfusions, replacement of blood and plasma components is based on both clinical status and laboratory investigations. Early correction of fibrinogen appears to be of greater importance in obstetric hemorrhage. Unlike non-obstetric massive hemorrhage, relying on frozen plasma for fibrinogen replacement may paradoxically cause a dilutional hypofibrinogenemia because of its relatively low concentration of fibrinogen (Table). Cell salvage, in combination with LDF, may be used in obstetric hemorrhage. There have been no proven cases of amniotic fluid embolus with washed red cells and filters. Fetal red cells pass through LDFs, but the risk of maternal alloimmunization is similar to that of vaginal delivery. ${ }^{28,29}$

The use of tranexamic acid in postpartum hemorrhage has remained inconsistent throughout the world, although its effectiveness in reducing blood loss has been shown in non-obstetric hemorrhage. The WOMAN collaborative, a randomized double-blind placebo-controlled study of over 20,000 obstetric patients, showed that tranexamic acid reduced death due to bleeding in women with postpartum hemorrhage, with no adverse effects. These patients received $1 \mathrm{~g}$ of tranexamic acid or placebo for postpartum hemorrhage after vaginal or Cesarean delivery. ${ }^{40}$ Tranexamic acid should be given as soon as possible after the onset of bleeding.

Fibrinogen concentrate is available in many countries, including Canada, and has been used in postpartum hemorrhage. It does have the advantage of easy mixing and administration, long shelf life, and a fairly consistent dose (Table). Increasing a serum fibrinogen level by 1.0 $\mathrm{g} \cdot \mathrm{L}^{-1}$ requires approximately $60 \mathrm{mg} \cdot \mathrm{kg}^{-1} \cdot 41,42$

The differences in the coagulation factors in obstetric $v s$ non-obstetric patients with massive hemorrhage are enough to warrant a specific massive transfusion protocol for obstetrics (MTPO) as well as an anesthesia checklist or algorithm.

\section{Massive transfusion protocol}

Massive transfusion protocol is found in most facilities that deal with trauma, obstetrics, cardiac, and other major surgeries. While the structure of an MTP may be specific for different institutions, there are common components that should be considered.

1. An MTP activation and deactivation process

2. Communication between the patient area and blood bank

3. Consistent blood component packs

4. Disposition of unused blood components

5. Activation of adjunct therapies

6. Consistent and timely laboratory testing

7. Ongoing audits of MTP

\section{Practical approach to the bleeding patient}

Any massive hemorrhage scenario has the potential for tension and chaos. Timely communication and an organized approach by the operating room team and the blood bank are essential. Even with experienced and adequate human resources, oversights or miscommunication can occur. In all cases, the goals are hemodynamic stability and cessation of bleeding. Adequate intravenous access takes priority over arterial or central monitoring. Consideration should be given to patient positioning to increase preload and cerebral perfusion. When indicated and accessible, cardiopulmonary resuscitation should be initiated. Warming devices (fluid/ blood and forced air) need to be employed as much as possible. As much of the patient's medical history as possible should be obtained to rule out other factors that may be contributing to the bleeding. While the transfusion of blood and plasma products is often based on clinical decisions, it is imperative to collect appropriate laboratory values on a timely basis to provide immediate feedback on the treatment regimen-as well as to retain as a useful audit tool.

Massive transfusion will be either successful or unsuccessful in treating massive hemorrhage. In some instances, surgical bleeding will appear to be controlled, but the resulting coagulopathy can result in ongoing hemorrhage. In such situations, the option of packing and later re-exploration may be a viable option to allow correction of acidosis, hypothermia, and anemia. Before transferring the patient to an intensive care setting, consideration should be given to remaining in the operating room for a period of at least $30 \mathrm{~min}$ to ensure that hemodynamic stability is maintained. With a further drop in hemoglobin, interventional radiology or early 
Figure Massive transfusion checklist

\section{Massive Transfusion Protocol (MTP) Checklist}

- Is raising the patient's legs possible? (Avoid head-up position)

- Inform transfusion medicine doctor "on call" that the MTP has been activated

- Call for help (e.g., anesthesia clinical assistant [ACA] or second anesthesiologist)

- Assign a nurse or ACA to check blood products and do charting

- Start arterial catheter after large-bore intravenous access has been established at two sites (14-16G peripheral intravenous lines preferred; consider large-bore sheath introducer or dialysis-type catheter)

- Is cell salvage an option? Call the perfusionist "on call"

- Send baseline blood work (type and screen, CBC, INR, fibrinogen, electrolytes/biochemistry)

- Has systemic anticoagulation been reversed?

- Is salvage surgery (i.e., packing and revisiting later) an option?

- Ask surgeon, "Should we call a vascular surgeon or other assistance for you?"

- Fluid/blood warmer (rapid infuser set up?)

- Forced air heater or other warming (if $<37^{\circ} \mathrm{C}$ )

- Should calcium administration be considered?

- Consider intravenous tranexamic acid $\left(15-30 \mathrm{mg} \cdot \mathrm{kg}^{-1}\right)$

- Consider $\mathrm{NaHCO}_{3}$ or THAM for a $\mathrm{pH}<7.2$

- Change blood filter every four transfusions if possible (and change the 3-L reservoir every four hours)

\begin{tabular}{|l|l|l|l|l|l|l|l|l|}
\hline Start time & Baseline & 1 hour & 2 hour & 3 hour & 4 hour & 5 hour & 6 hour & 7 hour \\
\hline $\mathrm{CBC}, \mathrm{INR}$, fibrinogen & & & & & & & & \\
\hline $\mathrm{Na}, \mathrm{Cl}, \mathrm{K}, \mathrm{Ca}, \mathrm{HCO}_{3}, \mathrm{Cr}$ & & & & & & & & \\
\hline $\mathrm{ABG}$ (at least hourly) & & & & & & & & \\
\hline $\begin{array}{l}\text { Temperature } \\
\text { (Continuous or hourly) }\end{array}$ & & & & & & & & \\
\hline
\end{tabular}

When bleeding is controlled/has stopped, patient has died, or resuscitation has stopped, inform the transfusion medicine doctor on call that MTP has ended. Promptly return unused products to the blood bank. $\mathrm{ABG}=$ arterial blood gas; $\mathrm{CBC}=$ cell blood count; $\mathrm{INR}=$ international normalized ratio; THAM = tris(hydroxymethyl)aminomethane. re-exploration may become a necessity. Consultation with a transfusion medicine specialist is appropriate at any stage of the massive transfusion.

Based on observation of MTPs, our institution has developed an anesthesia checklist, which is posted inside the operating room (Figure). It serves as a memory aid and also acts as an educational tool.

\section{Clinical case}

A 32-yr-old G3P2 woman with known placenta accreta is scheduled for an elective Cesarean delivery. She has had two previous Cesarean deliveries. She is otherwise healthy, weighs $72 \mathrm{~kg}$, and her preoperative hemoglobin is 118 $\mathrm{g} \cdot \mathrm{L}^{-1}$. With appropriate monitors and two sites of 
peripheral intravenous access ( $16 \mathrm{G}$ and $14 \mathrm{G})$, induction of general anesthesia is accomplished without complications.

Due to adhesions, the time from skin incision to uterine incision is $25 \mathrm{~min}$. The baby is born with Apgar scores of 5 and 9. Immediately after delivery, there is excessive hemorrhage; the patient's heart rate increases to 118 beats. $\min ^{-1}$, and her blood pressure initially drops to $84 /$ 52. Resuscitation with crystalloid is under way and blood is immediately available.

The blood loss is $1,900 \mathrm{~mL}$ and continuing. So far, the patient has received $2 \mathrm{~L}$ of Ringer's lactate solution as well as two units of red blood cells, and two more units are infusing. The massive transfusion protocol is implemented. Blood pressure is $90 / 60$ and heart rate is 120 beats $\cdot \min ^{-1}$. Laboratory results at this point reveal hemoglobin of 71 $\mathrm{g} \cdot \mathrm{L}^{-1}$, international normalized ratio (INR) of 1.1 , platelet count of 78,000, and fibrinogen of $1.9 \mathrm{~g} \cdot \mathrm{L}^{-1}$.

Instructions for completing the continuing professional development (CPD) module:

1. Read the current article and the references indicated in bold.

2. Go to: http://www.cas.ca/Members/CPD-Online and select the current module: Massive hemorrhage and transfusion in the operating room.

3. Answer the multiple-choice questions regarding the case scenario.

4. Once you have entered all of your answers, you will have access to experts' explanations for all the possible choices.

5. Participants may claim up to four hours of CPD, for a total of 12 credits under Section 3 of the CPD program of the Royal College of Physicians and Surgeons of Canada.

\section{L'hémorragie massive et la transfusion en salle d'opération}

\author{
Résumé \\ Objectif Dans ce module de Développement professionnel \\ continu, nous passons en revue la physiopathologie et les \\ manifestations cliniques associées à l'hémorragie massive \\ ainsi que les examens de laboratoire et les mesures \\ thérapeutiques adaptées. En plus de décrire les produits \\ sanguins / plasmatiques et traitements d'appoint \\ disponibles, nous explorons également le rôle de
}

l'anesthésiologiste dans une situation de transfusion massive.

Constatations principales Une hémorragie massive peut être anticipée ou inattendue. La présence concomitante d'acidose, d'hypothermie et d'hypotension contribue beaucoup à un mauvais pronostic. Non seulement les érythrocytes augmentent-ils la capacité de transport de l'oxygène, mais ils jouent également un rôle dans l'hémostase. Bien que les résultats de laboratoire soient importants, notamment les analyses au chevet, la transfusion demeure une décision clinique. Il a été démontré que les traitements d'appoint autres que les composants sanguins contribuaient à de meilleurs pronostics. La physiopathologie de l'hémorragie obstétricale massive est unique et ne se compare pas à la population non obstétricale. L'approche de l'hémorragie massive et de son traitement varie grandement d'un établissement à un autre.

Conclusion L'hémorragie massive est un défi multidisciplinaire qui requiert une réponse immédiate et une communication entre cliniciens, personnel infirmier et autres professionnels de la santé, tests de laboratoire et banques de sang. Les connaissances de base et l'utilisation des produits et traitements disponibles varient grandement. Un protocole de transfusion massive peut être utilisé de façon efficace pour réduire le chaos et garantir que les bons traitements et une posologie adaptée soient administrés rapidement.

\section{Objectifs de ce module de Développement professionnel continu (DPC):}

Après avoir lu ce module, le lecteur devrait être en mesure de:

1. Décrire les manifestations tant cliniques que physiopathologiques de l'hémorragie massive.

2. Commander des produits sanguins appropriés, à des doses et via une administration adéquates.

3. Énumérer les autres modalités thérapeutiques disponibles, outre les produits sanguins.

4. Organiser une liste de contrôle de transfusion massive.

\section{Définition et vue d'ensemble}

La définition de l'hémorragie massive ou de la transfusion massive varie d'un établissement à un autre. La définition traditionnelle de dix culots globulaires transfusés, ou d'une perte sanguine de plus d'un volume circulant au cours d'une période de 24 h, a été modifiée afin d'inclure la perte sanguine continue - par ex., quatre culots globulaires avec 
des saignements continus (certaines définitions spécifient un débit minimal par heure). Indépendamment de ces définitions, des signes d'hémorragie massive peuvent être cliniquement apparents bien avant que la transfusion ne soit amorcée.

La transfusion massive demeure l'un des plus grands défis auxquels est confronté l'anesthésiologiste. On l'observe le plus souvent dans les cas de traumatisme aigu, de chirurgie cardiaque complexe, d'hémorragie obstétricale et chez les patients souffrant de coagulopathie, mais elle peut également survenir lors de tout événement peropératoire. Dans certains cas elle peut être anticipée, résultant en une préparation adaptée et une réponse organisée, ou elle peut être inattendue, et provoquer une réponse de prime abord chaotique. Indépendamment du contexte, les objectifs de traitement en cas d'hémorragie massive sont de maintenir la pression de perfusion et l'apport d'oxygène aux organes, d'arrêter le saignement chirurgical, et de traiter toute coagulopathie. Bien que ces objectifs puissent être remplis par la réanimation à l'aide de produits sanguins et une intervention chirurgicale ou radiologique, la triade hypothermie / acidose / coagulopathie contribue à une morbidité et une mortalité accrues dans de telles situations. ${ }^{1-3}$ Alors que les tests sanguins de laboratoire, y compris les analyses de biologie délocalisées, constituent un outil important pour guider la transfusion, dans de nombreux cas le traitement se fonde sur la prise de décision clinique. Une transfusion massive implique une réanimation à l'aide d'érythrocytes et de produits plasmatiques. Des mesures autres que la transfusion de produits sanguins, notamment l'autotransfusion, les antifibrinolytiques, le remplacement des électrolytes/ liquidien et le maintien de la normothermie sont également nécessaires pour assurer un bon pronostic. La communication constante entre le chirurgien, l'anesthésiologiste et la banque de sang est essentielle. Une fois tous ces facteurs en place, il est important de disposer d'une stratégie planifiée. Pour de nombreux établissements, un protocole de transfusion massive (PTM) peut faciliter une approche organisée. En outre, une liste de contrôle anesthésique ('checklist') peut être utile.

\section{La physiopathologie de la coagulopathie}

Lors d'une hémorragie massive, l'hémostase comprend quatre processus majeurs. L'hémostase primaire consiste en la formation d'un clou plaquettaire qui comprend l'adhésion, l'agrégation ainsi que la vasoconstriction. L'hémostase secondaire se fait via l'activation des facteurs de coagulation pour générer de la thrombine. La troisième étape est la formation et la stabilisation de caillots de fibrine et, grâce à la formation de ces caillots, la quatrième étape d'inhibition de la thrombine et de fibrinolyse peut s'amorcer. ${ }^{4}$

Lorsqu'on prévoit toute intervention autre qu'une chirurgie périphérique mineure chez un patient souffrant d'un trouble de la coagulation, un plan détaillé de réponse à une perte sanguine devrait être préparé, en collaboration avec l'hématologue du patient. La prise en charge de troubles sous-jacents de la coagulation ne sera pas abordée dans ce compte-rendu. Toutefois, lorsqu'un tel patient se présente pour une chirurgie d'urgence ou un traumatisme aigu, les auteurs recommandent de consulter rapidement des spécialistes en hématologie et/ou en médecine transfusionnelle (selon les services disponibles dans votre établissement) avant que la perte de sang ne débute, si possible.

Lorsque des pertes sanguines et un remplacement cristalloïde se produisent, l'hémodilution qui s'ensuit peut entraîner chez les patients de chirurgie non urgente une hypercoagulabilité - telle que mesurée à l'aide de mesures de viscoélasticité (par ex., par thromboélastographie (TEG®)). Les implications pour les patients polytraumatisés ou les patientes obstétricales devant subir une chirurgie en état d'hypercoagulabilité ne sont pas claires. ${ }^{1}$

L'hypothermie quant à elle provoque une coagulopathie importante. ${ }^{2,3}$ Bien que les études cliniques aient donné des définitions diverses de l'hypothermie légère - la limite supérieure étant fréquemment établie à $35{ }^{\circ} \mathrm{C}$ - il est important de souligner que la détérioration de la fonction enzymatique est continue, non ordinale, et que la meilleure fonction s'observe à $37{ }^{\circ} \mathrm{C}^{5}$ L'hypothermie provoque une réduction de l'activation plaquettaire en raison d'une combinaison d'inhibition directe et d'un déclin des plaquettes circulantes par séquestration. L'activation de la cascade de coagulation est ralentie, la fibrinolyse accrue et la synthèse des facteurs de coagulation réduite. ${ }^{1,3}$

L'anémie contribue en soi à une coagulopathie plus avancée étant donné que les érythrocytes sont d'importants fournisseurs d'adénosine-diphosphate, laquelle contribue à l'activation plaquettaire. Les érythrocytes activent également la cyclo-oxygénase plaquettaire et fournissent des phospholipides procoagulants, lesquels jouent un rôle direct dans l'augmentation de génération de thrombine. ${ }^{1}$ En outre, les érythrocytes ont un effet rhéologique en s'agglomérant au centre des vaisseaux sanguins. On assiste ainsi à une concentration accrue de plaquettes dans le périmètre des vaisseaux, où elles peuvent être mieux exposées à un traumatisme endothélial et par conséquent activer et déclencher la coagulation. ${ }^{1,2} \mathrm{Ce}$ processus a un effet considérable et il a été démontré qu'il résultait en une concentration de plaquettes adjacentes aux 
parois vasculaires sept fois plus élevée que la moyenne. ${ }^{1,3,6}$ Un nombre important de données probantes existent, tant sur des modèles animaux et des volontaires sains que sur des modèles cliniques, d'une réduction de temps de saignement en cas de thrombopénie suivant la transfusion d'érythrocytes. Toutefois, la relation entre la durée du saignement et les pertes sanguines périopératoires demeure controversée, et la signification clinique d'une réduction de la durée de saignement n'est pas clairement établie. ${ }^{1} \mathrm{Chez}$ un patient en saignement actif, peu de données traitent du rôle de la concentration d'hémoglobine ou des hématocrites sur l'hémostase, mais les données probantes existantes tendent vers un hématocrite minimal pour une hémostase optimale. ${ }^{1,3}$ Hardy et coll. suggèrent que, dans un cas de saignement actif et de transfusion massive, un hématocrite aussi élevé que $35 \%$ pourrait être nécessaire pour soutenir l'hémostase. ${ }^{1}$ Il faut noter que la littérature oscille entre l'utilisation de l'hématocrite et de la concentration d'hémoglobine, mais chez un patient sans anémie macrocyte ou polykystique, les deux sont étroitement corrélés, avec un hématocrite de $35 \%$ correspondant à une concentration d'hémoglobine de $105-115 \mathrm{~g} \cdot \mathrm{L}^{-1}$.

L'épuisement des facteurs de coagulation est devenue une source de préoccupation dans l'ère moderne de transfusion de produits sanguins fractionnés, l'hypofibrinogénémie survenant en premier, suivie par une réduction critique de la prothrombine, du facteur $\mathrm{V}$, des plaquettes et du facteur VII, respectivement. Des taux de fibrinogène de 1,5-2,0 $\mathrm{g} \cdot \mathrm{L}^{-1}$ sont devenus le seuil de remplacement fibrinogénique chez tous les patients, hormis les femmes enceintes. ${ }^{1,8}$ Les plaquettes sont cruciales en raison de leur rôle de liaison aux fibrinogènes pour former des clous plaquettaires qui adhérent au collagène et au facteur von Willebrand ( $\mathrm{fvW}$ ) sur les parois vasculaires. Une thrombopénie importante d'un point de vue clinique est rare pendant la transfusion massive jusqu'à ce qu'environ un volume sanguin soit perdu. Cela est dû en partie à la concentration plaquettaire près des parois vasculaires, tel que précédemment décrit, ainsi qu'à la libération de plaquettes séquestrées et à la libération précoce de nouvelles plaquettes de la moelle osseuse. ${ }^{1}$

\section{Grossesse et hémostase}

La grossesse est une période d'hémostase déséquilibrée, avec une augmentation significative des facteurs procoagulants VIII, IX, X, XII et du fvW, une augmentation quasi double du fibrinogène, et une augmentation allant jusqu'à $1000 \%$ du facteur VII. ${ }^{9,10}$ Les taux de protéine $\mathrm{C}$ du facteur anticoagulant demeurent inchangés, bien que la résistance à la protéine $\mathrm{C}$ activée augmente, et les taux de protéine $\mathrm{S}$ tant liée que libre diminuent à partir du premier trimestre. ${ }^{9}$ On assiste à une réduction de l'activité fibrinolytique primaire pendant la grossesse et jusqu'au début de la période postpartum; cette réduction est bien documentée et survient malgré une augmentation de l'activité de l'activateur tissulaire du plasminogène pendant la grossesse. Cette activité est contrebalancée par une augmentation des inhibiteurs 1 et 2 des activateurs du plasminogène (ce dernier n'étant dépistable que pendant la grossesse). ${ }^{9,10}$ Il ne faut pas oublier que le système de coagulation est sur le fil du rasoir pendant la grossesse, avec une augmentation de quatre à dix fois du risque de thrombose. ${ }^{9}$ Cela réduit probablement le risque de morbidité et de mortalité maternelle lié au saignement, mais l'équilibre hématologique peut être adéquatement décrit, pendant la grossesse, comme une « coagulation intravasculaire disséminée compensée chronique $» .{ }^{11}$ Lors d'une hémorragie, il est important de reconnaître que des taux de fibrinogène considérés normaux en cas de non-grossesse sont alors gravement bas pour une patiente obstétricale. ${ }^{12,13}$

\section{Considérations touchant les produits sanguins et plasmatiques}

Les culots globulaires ont un hématocrite de 0,45 et une limite d'entreposage de 42 jours. La date de collecte et la date d'expiration sont indiquées sur le sac de collecte. Si la transfusion n'est pas amorcée dans les 30 min après retrait du réfrigérateur, le sac de collecte devrait y être remis, à température contrôlée. ${ }^{14} \mathrm{Il}$ est possible de garantir une capacité de transport d'oxygène adéquate avec des cibles d'hémoglobine de 70-90 $\mathrm{g} \cdot \mathrm{L}^{-1} ;^{15}$ toutefois, en cas d'hémorragie massive, le rôle des érythrocytes dans l'hémostase est de promouvoir l'activation des plaquettes et leur migration vers l'endothélium. ${ }^{1}$ Pour cette raison, une cible plus élevée d'hématocrite pourrait être indiquée. Lorsque possible, des érythrocytes sous pression devraient être transfusés via des cathéters à gros débit afin d'éviter une hyperkaliémie (due à l'hémolyse d'érythrocytes âgés ou à de petits cathéters). La charge potassique $\left(\mathrm{K}^{+}\right)$du sang conservé augmente avec la durée d'entreposage, les érythrocytes de 14 jours ayant une $\mathrm{K}^{+}$de 10-30 $\mathrm{mMol} \cdot \mathrm{L}^{-1} \cdot{ }^{16}$ L'administration centrale rapide d'érythrocytes froids peut exposer le cœur à une solution semblable à la cardioplégie froide de la chirurgie cardiaque, ${ }^{16,17}$ et la perfusion rapide d'érythrocytes a été associée à de nombreux arrêts cardiaques pédiatriques périopératoires dus à l'hyperkaliémie. ${ }^{18}$ Chez les petits patients, l'administration centrale et les situations de faible débit cardiaque augmentent le risque d'arrêt cardiaque provoqué par une hyperkaliémie. ${ }^{16}$ De récentes études ont 
démontré qu'il n'y avait pas de différence de pronostic selon la durée de conservation des érythrocytes. ${ }^{19,20} \mathrm{En}$ raison des quantités limitées d'érythrocytes/culots globulaires de donneurs $\mathrm{O}$ négatifs, on peut substituer des érythrocytes $\mathrm{O}$ positifs pour les patients adultes de sexe masculin dont on ne connaît pas le groupe sanguin, et pour les femmes adultes sans potentiel d'enfantement. ${ }^{21}$

Le plasma frais congelé peut être dérivé de donneurs aléatoires ou de donneurs par aphérèse en tant que plasma-aphérèse frais congelé (AFFP). Les unités de plasma frais congelé sont de $250 \mathrm{~mL}$ et les unités de d'AFFP sont d'environ $500 \mathrm{~mL} \cdot{ }^{14,22}$ Le plasma devrait être calculé au poids du patient $\left(10-15 \mathrm{~mL} \cdot \mathrm{kg}^{-1}\right)$ plutôt que par unité (deux unités de plasma pourraient correspondre à 500-1000 mL). Une fois décongelé, le plasma peut être conservé à $1-6^{\circ} \mathrm{C}$ pour une durée maximale de 120 heures. La concentration de fibrinogène dans le plasma est d'environ 2,5 g. $\mathrm{L}^{-1}$ (Tableau), ${ }^{23}$ ce qui contribue à la correction de l'hypofibrinogénémie chez un patient massivement transfusé. Cela pourrait par contre ne pas être le cas pour une patiente obstétricale souffrant d'une hémorragie massive, étant donné qu'un taux plus élevé de fibrinogène est nécessaire et que le plasma pourrait en fait provoquer une dilution du taux obstétrical normal de fibrinogène. $^{12}$

Les plaquettes transfusées sont dérivées des couches leucocyto-plaquettaires provenant de quatre donneurs (cinq au Québec). Leur durée de conservation à $20-24{ }^{\circ} \mathrm{C}$ va de cinq à sept jours (selon le degré de détection d'agents pathogènes). De nombreux établissements recommandent de transfuser les plaquettes via un filtre de transfusion neuf et de ne pas les utiliser dans un réchauffeur de sang ou un échangeur thermique, toutefois, peu de données appuient cette recommandation. De plus, la compatibilité du groupe sanguin et du facteur rhésus des plaquettes est préférable, mais non indispensable. ${ }^{14}$ Chaque dose de plaquettes devrait augmenter la numération de $15-25 \times 10^{9} \cdot \mathrm{L}^{-1}$.

Le cryoprécipité contient du facteur VII, du facteur VIII, $\mathrm{du}$ fibrinogène et du fvW. Le taux de fibrinogène varie beaucoup d'une unité de cryoprécipité à une autre (Tableau). Une unité de cryoprécipité par $10 \mathrm{~kg}$ de poids corporel augmentera le taux de fibrinogène d'environ 0,5 $\mathrm{g} \cdot \mathrm{L}^{-1}$. Le seuil de transfusion cible de $1,0 \mathrm{~g} \cdot \mathrm{L}^{-1}$ a été augmenté à $>1,5 \mathrm{~g} \cdot \mathrm{L}^{-1}$ dans plusieurs établissements ( $>2,5 \mathrm{~g} \cdot \mathrm{L}^{-1}$ en cas d'hémorragie obstétricale), mais le statut clinique pourrait justifier de ne pas attendre la confirmation d'une hypofibrinogénémie par le laboratoire. ${ }^{1,14}$

Le concentré de fibrinogène (CF) a été approuvé par Santé Canada et est de plus en plus disponible. Bien que des études cliniques comparant le $\mathrm{CF}$ au cryoprécipité soient en cours, le CF a l'avantage de subir un processus de réduction des agents pathogènes plus efficace, en plus d'avoir une durée de conservation de 30 mois à température ambiante. Ce produit est stable sous forme de solution pendant huit heures et ne nécessite pas de dispositif de perfusion sanguine avec filtre. La dose par flacon de CF est de 0,9-1,3 g (Tableau).

Les concentrés de complexe prothrombinique sont actuellement indiqués pour la neutralisation d'urgence d'un traitement à la warfarine. ${ }^{24}$ D'autres recherches sont nécessaires afin de déterminer s'il existe d'autres indications.

Il a été démontré que le facteur VIIa recombinant était efficace pour neutraliser la coagulopathie, mais il est associé à une augmentation de l'incidence de thrombose artérielle et ne peut être recommandé sauf pour un sauvetage de dernier recours. ${ }^{25}$

Tableau Liste de référence pour la commande des produits sanguins

\begin{tabular}{|c|c|c|}
\hline Produit sanguin & Composant & $\begin{array}{l}\text { Augmentation anticipée } \\
\text { après transfusion } \\
\text { à un patient de } 70 \mathrm{~kg}\end{array}$ \\
\hline \multicolumn{3}{|c|}{ Contenu en fibrinogène des produits disponibles pour le traitement de l'hypofibrinogénémie acquise } \\
\hline 1 flacon de concentré de fibrinogène & 0,9-1,3 g fibrinogène & $0,21-0,31 \mathrm{~g} \cdot \mathrm{L}^{-1}$ fibrinogène \\
\hline $1000 \mathrm{~mL}$ de plasma frais congelé (commandé tel que $10-15 \mathrm{~mL} \cdot \mathrm{kg}^{-1}$ ) & $2,94+/-0,63$ g fibrinogène $(1$ ÉT) & $0,57-0,89 \mathrm{~g} \cdot \mathrm{L}^{-1}$ fibrinogène \\
\hline 1 unité de cryoprécipité & 0,432 $(0,264) \mathrm{g}$ fibrinogène & $0,06 \mathrm{~g} \cdot \mathrm{L}^{-1}$ fibrinogène \\
\hline \multicolumn{3}{|l|}{ Contenu des produits pour le traitement de la thrombopénie et de l'anémie } \\
\hline 1 dose de plaquettes adulte & $311-373 \mathrm{~mL} ; 204-422 \times 10^{9} \mathrm{plt}$ & $15-25 \times 10^{9} \cdot \mathrm{L}^{-1} \mathrm{plt}$ \\
\hline 1 unité d'érythrocytes & 393-415 mL; 41-71 g Hgb & $10 \mathrm{~g} \cdot \mathrm{L}^{-1} \mathrm{Hgb}$ \\
\hline
\end{tabular}

$\mathrm{Hgb}=$ hémoglobine; plt = plaquettes. (Pour une version plus détaillée, voir références 14, 22 et 23 ) 


\section{Les traitements d'appoint}

Il existe plusieurs types de traitements d'appoint qui peuvent potentiellement réduire la morbidité, réduire les transfusions de sang homologue, et traiter ou retarder les coagulopathies induites afin de permettre la correction des facteurs médicaux et améliorer la coagulation. Lorsque survient une perte de sang considérable et inattendue, une chute précoce de la tension artérielle s'ensuit fréquemment, ce qui entraîne l'hypoperfusion des organes terminaux. Le remplacement rapide du volume liquidien est parfois retardé en raison d'un accès intraveineux limité. Il a été démontré qu'en plaçant le patient dans une position gynécologique forcée ou en surélevant les jambes droites, on pouvait augmenter la pression de perfusion coronaire et cérébrale et augmenter le débit cardiaque, respectivement, pendant cinq mais pas dix minutes. Il a été démontré que la position de Trendelenburg n'augmentait pas le débit cardiaque chez les patients après une chirurgie cardiaque ou lorsqu'ils étaient stables sous anesthésie. ${ }^{26}$ Dans le contexte d'une perte de sang soudaine, cependant, si une position gynécologique exagérée ou la surélévation des jambes droites n'est pas possible, nous suggérons une position de Trendelenburg jusqu'à $5^{\circ}$, ou de ramener le patient dans une position à niveau (c.-à-d., éviter de garder le patient dans une position tête en haut). Les bolus liquidiens et la transfusion de produits sanguins sont idéalement administrés via des canules intraveineuses périphériques de gros calibre, et le positionnement de ces canules devrait être l'un des premiers gestes à poser en cas d'hémorragie/transfusion massive. Si ce n'est pas faisable, un cathéter central de gros calibre (par ex., un cathéter introducteur de gaine ou un cathéter de dialyse) constitue une bonne alternative de deuxième intention.

Alors que l'objectif premier de la réanimation est d'augmenter la précharge afin de garantir un débit cardiaque adéquat, il est tout aussi important de maintenir une pression de perfusion adéquate aux organes vitaux. Un patient précédemment en bonne santé peut tolérer une fréquence cardiaque rapide et une réduction de débit pendant un court laps de temps, mais ce pourrait ne pas être le cas de patients qui présentent des comorbidités cardiaques, cérébrales ou rénales. Pour cette raison, les vasopresseurs peuvent s'avérer nécessaires dans le cadre d'une réanimation afin de favoriser l'apport d'oxygène au cœur et au cerveau, sachant que certains autres organes et tissus (notamment les reins et les extrémités) pourraient subir une lésion hypoxique plus grave.

Bien que l'utilisation et la posologie de l'acide tranexamique en cas d'hémorragie massive demeurent controversées, l'efficacité d'un agent antifibrinolytique dans le cadre d'une stratégie de correction de coagulopathie aiguë de trauma est devenue apparente. ${ }^{27}$
Le recours à un traitement d'autotransfusion peropératoire (ATPO - 'cell saver' en anglais) est maintenant répandu, mais des retards dans l'installation du matériel et la confusion constante parmi certains cliniciens quant à ses indications et contre-indications peuvent limiter son effet. L'autotransfusion peut être utilisée en cas de chirurgie pédiatrique et de chirurgie cardiaque, vasculaire, orthopédique, obstétricale et oncologique. ${ }^{28-30}$ Le recours à l'ATPO dans les chirurgies oncologiques demeure controversé, mais des données probantes rigoureuses ont montré que les cellules cancéreuses sont déjà présentes dans le sang de ces patients bien avant la plupart des chirurgies du cancer, et que l'ATPO réalisée avec des filtres de déleucocytation supprimait la plupart des cellules cancéreuses. ${ }^{28,30}$ Bien qu'il manque encore d'études randomisées de bonne qualité, la plupart des données probantes suggèrent que l'utilisation de l'ATPO avec des filtres de déleucocytation n'entraîne aucune différence en matière de survie à long terme et de récidive tumorale. ${ }^{28,30}$ Les contre-indications réelles à l'utilisation de l'ATPO en chirurgie oncologique se limitent aux situations où des tumeurs hépatocellulaires se sont rompues pendant l'opération. Dans les situations controversées de saignements massifs avec un intestin ouvert ou de liquide amniotique dans l'abdomen, les opinions d'experts recommandent le retrait initial de la matière fécale évidente à l'aide d'une succion séparée. Toutefois, la présence de matière fécale ou de liquide amniotique en cas de saignements importants ne constitue pas autrement une contre-indication à une ATPO réalisée avec filtre de déleucocytation. La contamination est prise en charge en augmentant le volume de bain et l'utilisation d'un filtre de déleucocytation. Cela entraîne des transfusats qui se rapprochent de ceux provenant de sources non contaminées. Dans les situations d'intestin ouvert où la matière fécale et la circulation du patient sont indistinctes, l'utilisation d'antibiotiques à large spectre est indiquée, qu'il y ait eu ATPO ou non. ${ }^{28}$ Il convient de souligner que des filtres de déleucocytation à charge négative augmentent les taux de bradykinine dans le produit transfusé, et que la perfusion rapide de sang récolté par ATPO avec une déleucocytation à un patient sous inhibiteurs de l'enzyme de conversion de l'angiotensine peut provoquer une hypotension réfractaire.

On décrit la chirurgie de sauvetage comme étant une approche pour les traumatismes graves qui se concentre sur le contrôle de la contamination et des sites d'hémorragie majeure, avec fermeture temporaire et retour subséquent en salle d'opération pour la réparation définitive, suite à la correction de l'acidose et de la coagulopathie. Il a été démontré que cette approche réduisait la mortalité comparativement à une réparation définitive primaire dans des cas de traumatismes majeurs. Les éléments 
cruciaux de cette approche, qui sont pertinents à n'importe quelle situation d'hémorragie massive, sont: la considération de packing des sites de saignement microvasculaire pour permettre la réanimation et la correction des troubles hématologiques et métaboliques, la considération d'une résection totale ou partielle de l'organe dans les contextes où le packing ne suffit pas à tamponner le saignement, la considération d'une dérivation artérielle ou veineuse pour contourner une lésion vasculaire critique afin de permettre une réparation définitive subséquente, et l'utilisation d'une embolisation intra-artérielle par radiologie interventionnelle pour contrôler les sites hémorragiques autrement inaccessibles. ${ }^{32}$

\section{Les tests de laboratoire}

Les électrolytes peuvent facilement être perturbés pendant une transfusion massive et devraient être mesurés et remplacés régulièrement afin d'éviter les conséquences d'un tel déséquilibre. En particulier, le calcium joue un rôle important dans la cascade de coagulation, et il a un effet inotrope sur la fonction cardiaque. ${ }^{1}$ Étant donné que les érythrocytes sont conservés dans du citrate, la transfusion d'importantes quantités de cet agent chélatant peut entraîner une hypocalcémie aiguë et nécessiter un remplacement régulier du calcium. ${ }^{2}$

Bien que les tests de formule sanguine complète, de rapport international normalisé et de fibrinogène réalisés dans un laboratoire central offrent les résultats les plus fiables, le délai typique associé à l'obtention de ces résultats et la nature dynamique de la transfusion massive signifie qu'ils indiquent souvent un état passé. Ils devraient tout de même être envoyés régulièrement, afin d'identifier des carences/déficits qui pourraient autrement ne pas être apparents ou ne pas avoir été corrigés dans l'intérim entre la collecte et la communication des résultats. ${ }^{2}$

Les analyses au chevet du patient ('point of care' en anglais) qui, selon l'établissement, peuvent comprendre l'analyse des gaz de sang artériel, l'hémoglobine / hématocrite, les électrolytes de base, le glucose, et/ou la mesure du lactate, permettent une évaluation opportune de divers paramètres et facilitent la prise en charge rapide.

Depuis une dizaine d'années, des tests de génération de thrombine et la capacité de coagulation totale sont disponibles au chevet du patient, notamment le TEG et la thromboélastométrie rotationnelle (ROTEM $\left.{ }^{\circledR}\right){ }^{33-36}$ Leurs éléments communs comprennent le placement de l'échantillon de sang dans une cuvette avec une goupille médiane. Dans le ROTEM, la goupille tourne et un système de détection optique est utilisé. Dans le TEG, la cuvette tourne, la goupille est stationnaire, et on mesure la torsion dans la goupille. ${ }^{33,35}$ Les deux modalités évaluent la rapidité et la force de formation de caillot ainsi que la stabilité du caillot, les défauts de certaines mesures spécifiques étant les cibles d'interventions spécifiques. À ce jour, aucune donnée probante concluante n'a observé de changement de mortalité ou d'incidence de transfusion massive lors de l'utilisation d'une transfusion guidée par ROTEM ou TEG. Cela est en grande partie dû à la prépondérance de petites études présentant un risque élevé de biais, ${ }^{34}$ mais la tendance montre tout de même une réduction dans la transfusion de produits sanguins, et des données probantes appuient leur efficacité en chirurgie cardiaque. ${ }^{34}$ Les résultats des deux tests (ROTEM et TEG) ne sont pas interchangeables, mais leurs implications cliniques sont semblables. ${ }^{37}$ Les plages de référence peuvent varier légèrement et doivent être disponibles pour l'appareil utilisé dans chaque établissement.

\section{L'hémorragie obstétricale massive}

Les définitions de l'hémorragie obstétricale massive comprennent une perte de sang $>2500 \mathrm{~mL}$, la transfusion de $\geq$ quatre culots globulaires, ou une chute de la concentration d'hémoglobine de $>40 \mathrm{~g} \cdot \mathrm{L}^{-1} \cdot{ }^{12}$ Les étiologies courantes comprennent l'atonie utérine, le traumatisme chirurgical, les anomalies placentaires et l'hématome rétroplacentaire, et la rupture utérine.

Les composantes de l'hémostase de la patiente obstétricale sont considérablement différentes d'une patiente non enceinte. Des augmentations des taux de facteurs de coagulation, y compris du fibrinogène, du fvW et du facteur VIII mettent la parturiente dans un état prothrombotique au terme de la grossesse. Les taux de fibrinogène de $4-6 \mathrm{~g} \cdot \mathrm{L}^{-1}$ sont deux fois plus élevés que chez la patiente non enceinte. ${ }^{38}$ La chute concomitante de la protéine $\mathrm{S}$ ajoute à cet état prothrombotique. Ces changements entraînent des temps de prothrombine (PT) et de thromboplastine/céphaline partielle activée plus courts (aPTT). Pour ces raisons, le PT et l'aPTT peuvent demeurer normaux malgré une hémorragie massive, bien que la réanimation liquidienne puisse provoquer une coagulopathie. Des PT et aPTT prolongés sont un signe de mauvais augure en cas d'hémorragie obstétricale et devraient être traités en conséquence. En outre, en raison en partie de l'activation de la fibrinolyse, une chute du fibrinogène à un taux de $2-3 \mathrm{~g} \cdot \mathrm{L}^{-1}$ est un signe pronostique précoce d'hémorragie massive. ${ }^{12,39}$ Outre les analyses de laboratoire standard, les analyses au chevet, notamment la thromboélastométrie, peuvent être des outils précieux pour évaluer l'hémostase lors d'une hémorragie obstétricale. ${ }^{34}$

Tout comme avec d'autres transfusions massives, le remplacement des composants sanguins et plasmatiques se fonde sur le statut clinique et les analyses de laboratoire. La 
correction précoce du fibrinogène semble être plus importante en cas d'hémorragie obstétricale. Au contraire de l'hémorragie massive non obstétricale, le fait de compter sur du plasma congelé pour remplacer le fibrinogène pourrait paradoxalement provoquer une hypofibrinogénémie dilutionnelle en raison de sa concentration relativement faible en fibrinogène (Tableau). L'autotransfusion, combinée à un filtre de déleucocytation, peut être utilisée en cas d'hémorragie obstétricale. Aucun cas prouvé d'embolie de liquide amniotique n'a été rapporté avec des culots globulaires lavés et des filtres. Les érythrocytes fœtaux traversent les filtres de déleucocytation, mais le risque d'allo-immunisation maternelle est semblable au risque encouru lors d'un accouchement vaginal. ${ }^{28,29}$

L'utilisation d'acide tranexamique en cas d'hémorragie postpartum est très variable de par le monde, bien que son efficacité pour réduire les pertes sanguines ait été démontrée dans des cas d'hémorragie non obstétricale. Le projet collaboratif WOMAN, une étude randomisée contrôlée par placebo à double insu portant sur 20000 patientes obstétricales, a démontré que l'acide tranexamique réduisait le nombre de décès dus aux saignements chez les femmes atteintes d'hémorragie postpartum, sans le moindre effet secondaire néfaste. Ces patientes ont reçu $1 \mathrm{~g}$ d'acide tranexamique ou un placebo pour traiter l'hémorragie postpartum après un accouchement vaginal ou par césarienne. ${ }^{40}$ L'acide tranexamique devrait être administré dès que possible après les premiers saignements.

Le concentré de fibrinogène est disponible dans de nombreux pays, y compris le Canada, et a été utilisé en cas d'hémorragie postpartum. Il a l'avantage d'être facile à mélanger et à administrer, d'avoir une longue durée de conservation, et un dosage relativement constant (Tableau). Pour augmenter le taux de fibrinogène sérique de 1,0 $\mathrm{g} \cdot \mathrm{L}^{-1}$, il faut environ $60 \mathrm{mg} \cdot \mathrm{kg}^{-1} \cdot 41,42$

Les différences de facteurs de coagulation entre des patientes obstétricales et des patients hors obstétrique souffrant d'une hémorragie massive suffisent à justifier l'emploi d'un protocole de transfusion massive spécifique pour l'obstétrique (PTMO) ainsi qu'une liste de contrôle ou un algorithme pour l'anesthésie.

\section{Le protocole de transfusion massive}

On trouve un protocole de transfusion massive dans la plupart des établissements qui traitent de chirurgies de trauma, obstétricales, cardiaques et autres chirurgies majeures. Bien que la structure d'un PTM puisse être spécifique à chaque établissement, certaines composantes communes doivent être présentes.
1. Un processus d'activation et de désactivation du PTM

2. La communication entre la zone patient et la banque de sang

3. Des sacs de produits sanguins de taille et de qualité constantes

4. Un processus pour le retour des produits sanguins inutilisés à la banque de sang

5. L'activation des traitements d'appoint

6. Des analyses de laboratoire cohérentes et opportunes

7. Des mécanismes de surveillance en continu des PTM.

\section{Approche pratique du patient en saignement}

Tout cas d'hémorragie massive a le potentiel de créer tension et chaos. Une bonne communication et une approche organisée par l'équipe de la salle d'opération et la banque de sang sont essentielles. Même si l'on dispose de ressources humaines adéquates et expérimentées, les oublis et la mauvaise communication peuvent survenir. Dans tous les cas, les objectifs de la prise en charge sont la stabilité hémodynamique et l'interruption des saignements. Un accès intraveineux adapté est prioritaire et devrait être sécurisé avant d'installer tout monitorage artériel ou central. Il faut penser à changer au besoin la position du patient afin d'augmenter la précharge et la perfusion cérébrale. Une réanimation cardiorespiratoire devrait être amorcée si elle est indiquée et accessible. Des dispositifs de réchauffement (liquide/sang et air forcé) doivent être employés autant que possible. Il faut obtenir le maximum d'informations possibles concernant les antécédents médicaux du patient afin d'éliminer les autres facteurs qui pourraient contribuer aux saignements. Bien que la transfusion de produits sanguins et plasmatiques se fonde souvent sur des décisions cliniques, il est impératif de recueillir des valeurs de laboratoire fréquentes afin de guider la réponse thérapeutique immédiate - et de les conserver à titre d'outil de contrôle ultérieur.

Une transfusion massive réussira ou échouera à traiter une hémorragie massive. Dans certains cas, le saignement chirurgical semblera être sous contrôle, mais la coagulopathie qui en résultera pourrait entraîner une hémorragie continue. Dans de telles situations, l'option de refermer puis de procéder à une nouvelle exploration plus tard pourrait constituer une option viable afin de permettre de corriger l'acidose, l'hypothermie et l'anémie. Avant de transférer le patient aux soins intensifs, on peut envisager de rester en salle d'opération pour une période d'au moins $30 \mathrm{~min}$ afin de garantir le maintien de la stabilité hémodynamique. $\mathrm{Si}$ une autre chute de l'hémoglobine survenait, une radiologie interventionnelle ou une ré-exploration précoce pourraient s'avérer 
Figure Liste de contrôle pour la transfusion massive

\section{Liste de contrôle du Protocole de transfusion massive (PTM)}

○ Est-il possible de surélever les jambes du patient? (éviter une position la tête en haut)

- Informer le médecin spécialiste de médecine transfusionnelle « de garde » que le PTM a été activé

- Demander du renfort (par ex., assistant clinique en anesthésie ou deuxième anesthésiologiste)

- Assigner à une infirmière ou un assistant clinique de vérifier les produits sanguins et de les consigner au dossier

- Amorcer un cathéter artériel après l'installation d'un accès intraveineux de gros calibre à deux endroits (lignes intraveineuses périphériques de 14-16G de préférence; envisager un cathéter introducteur de gaine ou de dialyse)

- L'autotransfusion est-elle une option? Appeler le perfusionniste « de garde »

- Envoyer les analyses sanguines de base (groupe et dépistage, FSC, RIN, fibrinogène, électrolytes/biochimie)

- L'anticoagulation systémique a-t-elle été neutralisée?

- La chirurgie de sauvetage (c.-à-d. fermeture et reprise ultérieure) est-elle une option?

- Demander au chirurgien, «Est-ce qu'il faut appeler un chirurgien vasculaire ou d'autres renforts pour vous?»

- Réchauffeur de liquide/sang (perfusion rapide installée?)

- Chauffage à air forcé ou autre dispositif de chauffage $\left(\mathrm{si}<37^{\circ} \mathrm{C}\right)$

- Doit-on envisager une administration de calcium?

- Envisager l'administration intraveineuse d'acide tranexamique $\left(15-30 \mathrm{mg} \cdot \mathrm{kg}^{-1}\right)$

- Envisager l'administration de $\mathrm{NaHCO}_{3}$ ou de THAM pour un $\mathrm{pH}<7,2$

- Changer le filtre sanguin toutes les quatre transfusions si possible (et changer le réservoir de $3 \mathrm{~L}$ aux quatre heures)

\begin{tabular}{|l|l|l|l|l|l|l|l|l|}
\hline Heure de début & Base & $\begin{array}{l}1 \\
\text { heure }\end{array}$ & $\begin{array}{l}2 \\
\text { heures }\end{array}$ & $\begin{array}{l}3 \\
\text { heures }\end{array}$ & $\begin{array}{l}4 \\
\text { heures }\end{array}$ & $\begin{array}{l}5 \\
\text { heures }\end{array}$ & $\begin{array}{l}6 \\
\text { heures }\end{array}$ & $\begin{array}{l}7 \\
\text { heures }\end{array}$ \\
\hline FSC, RIN, fibrinogène & & & & & & & & \\
\hline $\mathrm{Na}, \mathrm{Cl}, \mathrm{K}, \mathrm{Ca}, \mathrm{HCO}_{3}, \mathrm{Cr}$ & & & & & & & \\
\hline $\begin{array}{l}\mathrm{GSA}(\mathrm{au} \text { moins une fois par } \\
\text { heure) }\end{array}$ & & & & & & & & \\
\hline $\begin{array}{l}\text { Température } \\
\text { (en continu ou une fois / } \\
\text { heure) }\end{array}$ & & & & & & & & \\
\hline
\end{tabular}

Lorsque le saignement est sous contrôle / a cessé, le patient est décédé, ou la réanimation est interrompue, informer le médecin spécialiste de médecine transfusionnelle que le PTM est terminé. Retourner sans délai les produits non utilisés à la banque de sang. GSA = gazométrie du sang artériel; FSC = formule sanguine complète; RIN = rapport international normalisé; THAM = tris-(hydroxyméthyl) aminométhane. 
nécessaires. Il convient de consulter un spécialiste de la médecine transfusionnelle à tout moment au cours d'une transfusion massive.

En se fondant sur l'observation des PTM, notre établissement a mis au point une liste de contrôle pour l'anesthésie, laquelle est affichée à l'intérieur de la salle d'opération (Figure). Elle sert d'aide-mémoire et agit également comme outil éducationnel.

\section{Cas clinique}

Une femme de 32 ans, mère de deux enfants et enceinte pour la $3^{\mathrm{e}}$ fois, avec un placenta accreta diagnostiqué, doit subir un accouchement par césarienne non urgent. Elle a déjà eu deux accouchements par césarienne. Elle est autrement en bonne santé, pèse $72 \mathrm{~kg}$ et son hémoglobine préopératoire est de $118 \mathrm{~g} \cdot \mathrm{L}^{-1}$. Une fois les moniteurs adaptés et deux sites d'accès intraveineux périphériques installés (16G et 14G), l'induction de l'anesthésie générale se fait sans complications.

En raison d'adhérences, le temps entre l'incision de la peau et l'incision utérine est de 25 min. Le bébé est né avec des scores Apgar de 5 et 9. Immédiatement après l'accouchement, on assiste à une hémorragie excessive; la fréquence cardiaque de la patiente augmente à 118 battements. $\mathrm{min}^{-1}$, et sa tension artérielle chute initialement à 84/52. La réanimation à l'aide de cristalloïdes est en cours et du sang est immédiatement disponible.

La perte sanguine est de $1900 \mathrm{~mL}$ et persiste. Jusqu'à maintenant, la patiente a reçu $2 \mathrm{~L}$ de solution de Ringer ainsi que deux culots globulaires, et deux culots supplémentaires sont en cours de transfusion. Le protocole de transfusion massive est mis en œuvre. La tension artérielle est de 90/60 et la fréquence cardiaque de 120 battements $\cdot \min ^{-1}$. Les résultats de laboratoire à ce moment-ci révèlent une hémoglobine de $71 \mathrm{~g} \cdot \mathrm{L}^{-1}$, un rapport international normalisé de 1,1 , une numération plaquettaire de 78000 et un fibrinogène de $1,9 \mathrm{~g} \cdot \mathrm{L}^{-1}$.

\section{Directives pour compléter le module de développement professionnel continu (DPC) :}

1. Lisez cet article et les références en gras.

2. Allez à : http://www.cas.ca/Membres/modules-de-DPC et choisissez le module actuel : L'hémorragie massive et la transfusion en salle d'opération

3. Répondez aux questions à choix multiples portant sur le cas clinique.
4. Une fois que vous aurez répondu à toutes les questions, vous aurez accès aux explications d'experts pour tous les choix possibles.

5. Les participants peuvent réclamer un maximum de quatre heures de DPC pour un total de 12 crédits sous la Section 3 du programme de DPC du Collège royal des médecins et chirurgiens du Canada.

Conflicts of interest None declared.

Editorial responsibility This submission was handled by Dr. Stéphane Lambert, CPD Editor, Canadian Journal of Anesthesia.

Funding sources None.

Conflit d'intérêt Aucun.

Responsabilité éditoriale Cet article a été traité par Dr Stéphane Lambert, rédacteur des DPC, Journal canadien d'anesthésie.

Sources de financement Aucune.

\section{References}

1. Hardy JF, de Moerloose P, Samama CM; Members of the Groupe d'Intérêt en Hémostase Périopératoire. Massive transfusion and coagulopathy: pathophysiology and implications for clinical management. Can J Anesth 2006; 53(6 Suppl): S40-58.

2. Pham HP, Shaz BH. Update on massive transfusion. Br J Anaesth 2013; 111 (suppl_1): i71-82.

3. Lier H, Krep H, Schroeder S, Stuber F. Preconditions of hemostasis in trauma: a review. the influence of acidosis, hypocalcemia, anemia, and hypothermia on functional hemostasis in trauma. J Trauma 2008; 65: 951-60.

4. Luchtman-Jones L, Broze GJ Jr. The current status of coagulation. Ann Med 1995; 27: 47-52.

5. Michelson AD, MacGregor H, Barnard MR, Kestin AS, Rohrer MJ, Valeri $C R$. Reversible inhibition of human platelet activation by hypothermia in vivo and in vitro. Thromb Haemost 1994; 71: 633-40.

6. Blajchman MA, Bordin JO, Bardossy L, Heddle NM. The contribution of the haematocrit to thrombocytopenic bleeding in experimental animals. Br J Haematol 1994; 86: 347-50.

7. Nijboer JM, van der Horst IC, Hendriks HG, ten Duis HJ, Nijsten $M W$. Myth or reality: hematocrit and hemoglobin differ in trauma. J Trauma 2007; 62: 1310-2.

8. Hiippala ST, Myllyla GJ, Vahtera EM. Hemostatic factors and replacement of major blood loss with plasma-poor red cell concentrates. Anesth Analg 1995; 81: 360-5.

9. Brenner B. Haemostatic changes in pregnancy. Thromb Res 2004; 114: 409-14.

10. Cerneca $F$, Ricci $G$, Simeone $R$, Malisano $M$, Alberico $S$, Guaschino $S$. Coagulation and fibrinolysis changes in normal pregnancy. Increased levels of procoagulants and reduced levels of inhibitors during pregnancy induce a hypercoagulable state, combined with a reactive fibrinolysis. Eur J Obstet Gynecol Reprod Biol 1997; 73: 31-6.

11. Braveman FR, Scavone BM, Blessing ME, Wong CA. Obstetrical anesthesia. In: Cahalan M, Cullen BF, Stock MC, Stoelting RK. Clinical Anesthesia, $7^{\text {th }}$ Edition. Lippincott Williams \& Wilkins; 2013. 
12. Collis RE, Collins PW. Haemostatic management of obstetric haemorrhage. Anaesthesia 2015; 70: 78-e28.

13. Pavord $S$, Maybury $H$. How I treat postpartum hemorrhage. Blood 2015; 125: 2759-70.

14. Callum JL. Bloody Easy 4. Ontario Regional Blood Coordinating Network; 2016.

15. Hebert PC, Wells G, Blajchman MA, et al. A multicenter, randomized, controlled clinical trial of transfusion requirements in critical care. Transfusion Requirements in Critical Care Investigators, Canadian Critical Care Trials Group. N Engl J Med 1999; 340: 409-17.

16. Brown KA, Bissonnette B, McIntyre B. Hyperkalaemia during rapid blood transfusion and hypovolaemic cardiac arrest in children. Can J Anesth 1990; 37: 747-54.

17. Baxter Healthcare Corporation. Cardioplegic injection, solution 1997. Available from URL: https://dailymed.nlm.nih.gov/ dailymed/archives/fdaDrugInfo.cfm?archiveid=8625 (accessed May 2017)

18. Bhananker SM, Ramamoorthy C, Geiduschek JM, et al. Anesthesia-related cardiac arrest in children: update from the Pediatric Perioperative Cardiac Arrest Registry. Anesth Analg 2007; 105: 344-50.

19. Lacroix J, Hebert PC, Fergusson DA, et al. Age of transfused blood in critically ill adults. N Engl J Med 2015; 372: 1410-8.

20. Heddle NM, Cook RJ, Arnold DM, et al. Effect of short-term vs. long-term blood storage on mortality after transfusion. $\mathrm{N}$ Engl $\mathrm{J}$ Med 2016; 375: 1937-45.

21. Choosing Wisely Canada and the Canadian Society for Transfusion Medicine (CSTM). Choosing wisely Canada. Available from URL: http://www.choosingwiselycanada.org/ recommendations/transfusion-medicine/ (accessed May 2017).

22. Canadian Blood Services. Plasma Components (FFPA, FP CPD, Cryosupernatant CPD, Cryoprecipitate CPD. 2016. page 4. Available from URL: https://professionaleducation.blood.ca/ sites/msi/files/chapters/CGTTChapter2_MAR2013_FINAL.pdf (accessed May 2017).

23. Sheffield WP, Bhakta V, Talbot K, Pryzdial ELG, Jenkins C. Quality of frozen transfusable plasma prepared from whole blood donations in Canada: an update. Transfus Apher Sci 2013; 49: 440-6.

24. Nahirniak S, Ahluwalia N, Berry B, et al. Recommendations for use of prothrombin complex concentrates in Canada. National Advisory Committee on Blood and Blood Products; 2014: 9. Available from URL: http://www.nacblood.ca/resources/ guidelines/PCC-Recommendations-Final-2014-05-16.pdf (accessed May 2017).

25. Lin Y, Moltzan CJ. Anderson DR; National Advisory Committee on Blood and Blood Products. The evidence for the use of recombinant factor VIIa in massive bleeding: revision of the transfusion policy framework. Transfus Med 2012; 22: 383-94.

26. Kweon TD, Jung $C W$, Park JW, Jeon YS, Bahk JH. Hemodynamic effect of full flexion of the hips and knees in the supine position: a comparison with straight leg raising. Korean $\mathbf{J}$ Anesthesiol 2012; 62: 317-21.

27. Napolitano LM, Cohen MJ, Cotton BA, Schreiber MA, Moore EE. Tranexamic acid in trauma: how should we use it? J Trauma Acute Care Surg 2013; 74: 1575-86.
28. Ashworth A, Klein AA. Cell salvage as part of a blood conservation strategy in anaesthesia. Br J Anaesth 2010; 105: 401-16.

29. Allam J, Cox M, Yentis SM. Cell salvage in obstetrics. Int J Obstet Anesth 2008; 17: 37-45.

30. Trudeau JD, Waters T, Chipperfield $K$. Should intraoperative cell-salvaged blood be used in patients with suspected or known malignancy? Can J Anesth 2012; 59: 1058-70.

31. Sreelakshmi TR, Eldridge J. Acute hypotension associated with leucocyte depletion filters during cell salvaged blood transfusion. Anaesthesia 2009; 65: 742-4.

32. Lamb CM, MacGoey P, Navarro AP, Brooks AJ. Damage control surgery in the era of damage control resuscitation. Br J Anaesth 2014; 113: 242-9.

33. Armstrong $S$, Fernando $R$, Ashpole $K$, Simons $R$, Columb $M$. Assessment of coagulation in the obstetric population using ROTEM ${ }^{\circledR}$ thromboelastometry. Int J Obstet Anesth 2011; 20: 293-8.

34. Wikkelso A, Wetterslev J, Moller AM, Afshari A. Thromboelastography (TEG) or thromboelastometry (ROTEM) to monitor haemostatic treatment versus usual care in adults or children with bleeding. Cochrane Database Syst Rev 2016; 8: CD007871.

35. Macafee B, Campbell JP, Ashpole K, et al. Reference ranges for thromboelastography (TEG $\left.{ }^{\circledR}\right)$ and traditional coagulation tests in term parturients undergoing caesarean section under spinal anaesthesia. Anaesthesia 2012; 67: 741-7.

36. Ogawa S, Szlam F, Bolliger D, Nishimura T, Chen EP, Tanaka $K A$. The impact of hematocrit on fibrin clot formation assessed by rotational thromboelastometry. Anesth Analg 2012; 115: 16-21.

37. Rizoli $S$, Min A, Sanchez AP, et al. In trauma, conventional ROTEM and TEG results are not interchangeable but are similar in clinical applicability. Mil Med 2016; 181(5 Suppl): 117-26.

38. Szecsi PB, Jorgensen M, Klajnbard A, Andersen MR, Colov NP, Stender $S$. Haemostatic reference intervals in pregnancy. Thromb Haemost 2010; 103: 718-27.

39. Charbit B, Mandelbrot L, Samain E, et al. The decrease of fibrinogen is an early predictor of the severity of postpartum hemorrhage. J Thromb Haemost 2007; 5: 266-73.

40. WOMAN Trial Collaborators. Effect of early tranexamic acid administration on mortality, hysterectomy, and other morbidities in women with post-partum hemorrhage (WOMAN): an international, randomized, double-blind, placebo-controlled trial. Lancet 2017. DOI:10.1016/S0140-6736(17)30638-4.

41. Bosch Y, Al Dieri R, ten Cate H, et al. Preoperative thrombin generation is predictive for the risk of blood loss after cardiac surgery: a research article. J Cardiothorac Surg 2013; 8: 154.

42. Karkouti K, Callum J, Wijeysundera DN, et al. Point-of-care hemostatic testing in cardiac surgery: a stepped-wedge clustered randomized controlled trial. Circulation 2016; 134: 1152-62.

43. Vraets A, Lin Y, Callum JL. Transfusion-associated hyperkalemia. Transfus Med Rev 2011; 25: 184-96. 